\title{
The seismicity of Tunis
}

\author{
X. X. AMUR ISEYS (*) \\ Riceruto il 5 settembre I962
}

\section{1. - Ixthodvetion.}

Very little is known regarding the seismieity of Tunisia and in particular that of the Tunis area. We know that Tunis was shaken a few times in the past but it is rather difficult to say with certainty what effect these earthquakes had on struetures and what their intensities were. Information is particularly lacking about those earthquakes before the 19th century. It may, however, be significant that historical records for the area of Tunis indicate intense seismic activity during the 9 th and 18 th centuries, although one must make some allowances for natural exaggerations in early statements.

In order to disclose the seismic potentiality of such a poorly doetumented area it is, therefore, essential to resort to its geotectonic history for information.

\section{2. - TECTONICS $(* *)$.}

The Tunis area belongs to the extreme north end of the Atlas momtains. These mountains constitute a greological unit distinct from the rest of the African continent, the north part of which is an active orogenic block. This block extends from Cape Nun and Agadir in Moroceo to the Gulf of Gabes in Tunisia, a distance of 1500 miles. It is bounded on the north by the Mediterranean Sea and on the south by the Sahara desert.

$\left(^{*}\right)$ Department of Civil Eng.. Imperial College of sci.. London, s. W. 7. (**) $(1,8,9,10,12,19,20,26)$. 
The Atlas mountains can be roughly divided into two main chains which are separated by high plateaus, the Matritime Atlas, and the Sahara Atlas. The two mountain ehains approach oach other gradually and come together in Tunisia, where, near Zaghouan, they are separated by a nearly vertical fracture. The north-east part of the fractured mass has been lifted by comparatively recent orogenic: movements to a height of nearly 4500 feet with respect to the sonth-east part, thus forming Cape Bon on the east and the Gulf of Tunis on the west. This orogenic movement also explains the abrupt turning of the African coast southwards and the formation of the Sonsse-Gabes coast.

The Atlas mountains were uplifted during the Alpine crustal movements. The movements commenced at the end of the Jurassice period, were renewed in the Epper Cretaceous and continued into the Middle and probably Upper Miocene. There is also evidence of folding during earlier periods, with a dominant direction of movement from north to south. More recent movements have left ample evidence in the morplology of the area, in which Tunis is situated.

There is little doubt that Tunis belongs to that orogenic zone and that it is seismically unstable. In point of fact this area is still undergoing tectonic readjustments which occur at a comparatively slow mate. The existence of a number of active faults in north Tunisia is also in agreement with the orogenies of the area. Figure 1 shows some of the well known faults in Tunisia and their relation with inferred and instrumentally determined epicentres of earthquake shocks. As a matter of interest the epicentres for several more distant earthquakes have been included, the majority of which belong to shocks of class ' $d$ ' $\left({ }^{13}\right)\left({ }^{*}\right)$.

Sieberg (1932) and De Ballore (1906) show a number of epicentres right in Tunis and Rothe (1951) suggests some activity on the extension of the fault of Djabel-Naheli at the end of the hills and the Bahira Lake (Lake of Tunis). This, places Tunis literally on a fault, presumably active and responsible for at least one known earthquake of intensity VI on the Modified Merealli Suale $\left({ }^{25}\right)$.

\section{3. - Seishic His'ory.}

A survey of the seismic history of north Tunisia, although based on fragmentary data, shows that the country has from the earliest periods

(*) Epicentres wore obtainerl from (6, 7, 13, 16, 24). 
of history been subject to rather frequent earthquake shocks. MIost of these shocks appear to have been slight and even on the worst cases, they have fallen below the average of destructive earthquakes.

This is particularly so if, as we have to, base our assessments of intensity on historically recorded maximum effects of earthquakes on structures. Such records tend to represent the behaviour of the worst structures, during an earthefuake or, the behaviour of structuses on the worst ground.

In the first instance, since most of the ordinary houses in North Africa are very poorly built, some of which simply invite earthquake damage, any assessment of intensity from damage to such structures would be highly overestimated.

On the other hand, the worst ground is commonly found on the shores or in alluvial and marshy areas, and these are the locations of the older centres which furnish much of the data.

For these reasons an unmodified application of old data, particularly when natural exaggerations are not taken into consideration, will lead to apparent concentration of seismicity in small areas surrounding the largest and oldest centres of culture, which in our case are Kairowan, Tunis, and Utica.

A summary table of all those shocks which caused some damage or concern in Tunisia is given at the end of the paper (*). This table is admittedly incomplete, but it suggests that light shocks are frequent and that strong ones occur ar rather long intervals of time (**). This long periodicity of comparatively strong earthquakes in Tunisia seems to be typical of the orogenies of the two extreme ends of the Atlas block. At the ends of the Atlas range crustal a justements appear to dissipate their potential energy by numerous but light shocks, and hence from the seismic point of view, cause little concern. In the central part of the range, however, the readjustements are more sudden and much more severe.

Most probably much of the seismic: activity in north Tunisia is associated with the Zaghouan fault along which recent orogenic movements have resulted in the differential elevation of the south side of the

(*) Professor J. P. Rothè of Strasbourg has prepared an earthquake catalogue for Tunisia which contains all shocks for which there is information available.

(**) This statement is not inconsistent with the material in Professor Rothè's catalogue. 
Zaghouan massive. The north flank of the Zaghouan mountains thus formed coincide with the Zaghouan fault which runs throught the Gulf of Tunis and is largely responsible for the separation of Cape Bon from the rest of the north Africa coast.

It is due to this fault that north Tunisia shows such a high seismic activity. De Ballore (1906) attributes the destructives earthquakes of the 5th century and a number of more recent ones to activity of this fault or of one of its northern branches. He considers that the only active part of Tunisia is the area north of Sousse and Krenkel (1923) agrees with this opinion but includes also the whole of the north Atlas zone of Algeria. Sieberg (1932) indicates that the region on both sides of the Zaghouan fault as well as a zone within a radius of 100 miles of Tunis are the most precarious and seismic areas in Tunisia. A similar statement is made by Barkov (1953).

\section{4. - SEISMICITY.}

Taking into consideration the data shown on Figure 1 and the information available on the tectonies and seismicity of Tunisia - which is neither ample nor accurate - the country has been divided into three principal seismic zones. Zones " $\mathrm{A}$ ". " $\mathrm{B}$ " and " $\mathrm{O}$ " indicate respectively regions where strong, intense or light earthquakes are likely to occur $\left({ }^{*}\right)$. This division is tentative and it is shown on Figure 2 . The reliability and accuracy of the available data is so low that an extensive treatment of these data, in order to arrive at an intensity zoning of the country, was considered to be unwarranted.

It is desirable, however, to assess the seismicity at Tunis, or rather' the intensity of the strongest probable earthquake for the area of Tunis. $\Lambda t$ this stage, this is almost certainly impossible because of the complete lack of information concerning the tectonics and seismicity of the area.

We must resort, therefore, to the plausible conjecture usually employed in such cases, of the repetition of a past strong earthquake at the minimum epicentral distance which is justified by the tectonies of the region. In the present case this would leard to the assumption that an arthquake of the same characteristics as the Agadir earthquake (11) could

(*) The boundaries of zone " $C$ " are rather tentative. Parts of this zone may well belong either to zone "A" or zone "B" but the available information is insulficient to define the limits with any accuracy. 
occur on the Djabel Naheli, or on one of the branches of the Zaghouan fault. This assumption is of course open to criticism, but, in the complete absence of information for the probable character of strong ground

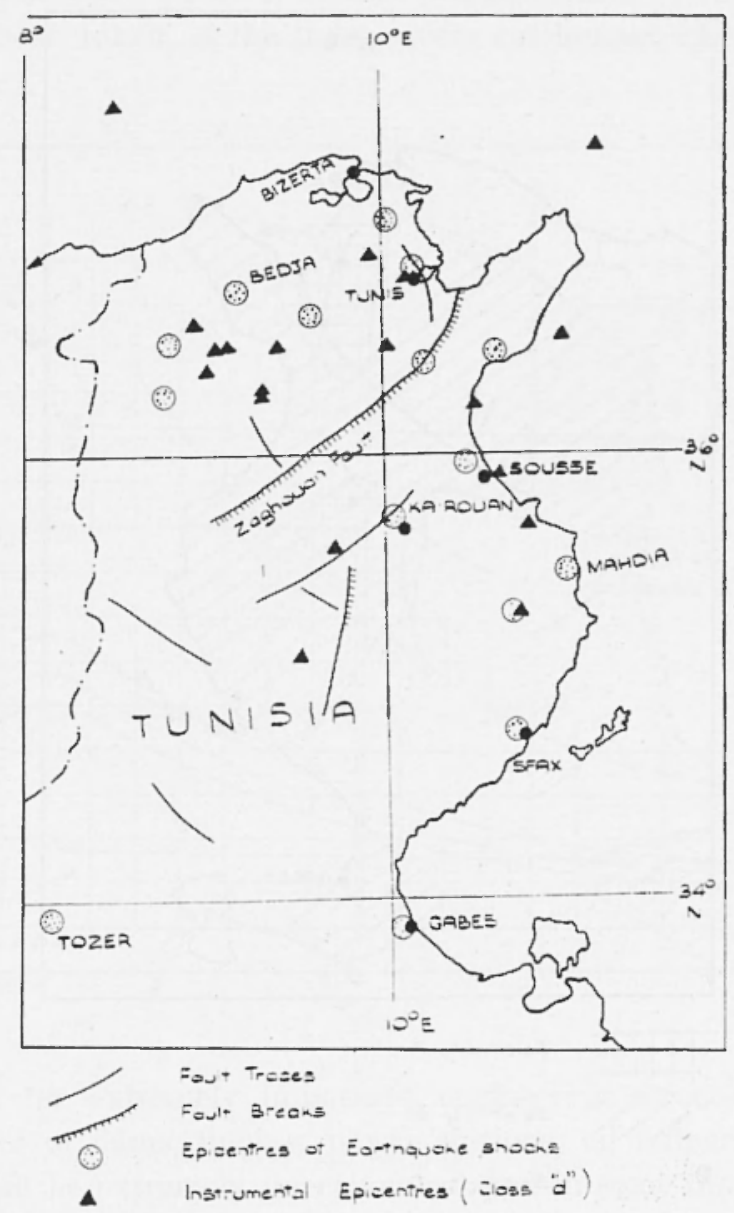

Fig. 1

movements at Tunis, it constitutes a reasonable upper limit for the seismic intensity of a damaging earthquake occurring in this area.

\section{5. - Design Spectrum.}

The Agadir earthquake was a low-magnitude earthquake with extremely shallow focus and high intensity $\left({ }^{11,17}\right)$. The velocity spectrum 
for the Agadir earthquake was constructed by Kirkland (1962) from which the corresponding acceleration spectrum has been computed for a critical damping of $10 \%$. This is shown on Figure 3 , curve " $\Lambda$ ",

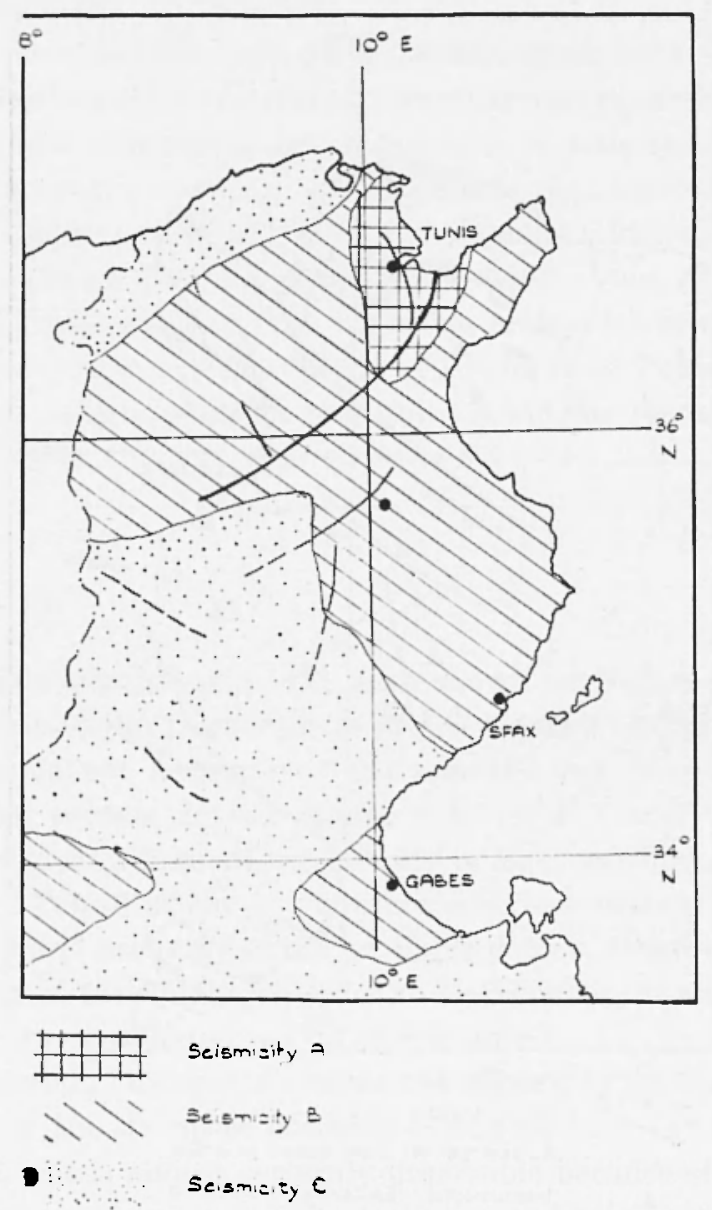

Fir. 2

and a conservative approach would be to adopt curve " $A$ " for the design of important engineering structures within a radius of 50 miles from Tunis, together with one of the recognised Building Codes for seismic regions $(2,5,15,17,22,28)$.

The way acceleration or velocity spectra are used for the design of structures to resist earthquake forces is given in many references $(2,5,15,28)$ and this problem will not be discussed. 
Some comments on the use of curve "A" (Figure 3 ) in the design of structures are necessary. If curve " $A$ " is used, the structure should be designed to be strong enough to resist, without plastic deformation (elastically), an earthquake of similar characteristics to that at Agadir, which has been taken as the most severe earthquake likely to occur in Tunis.

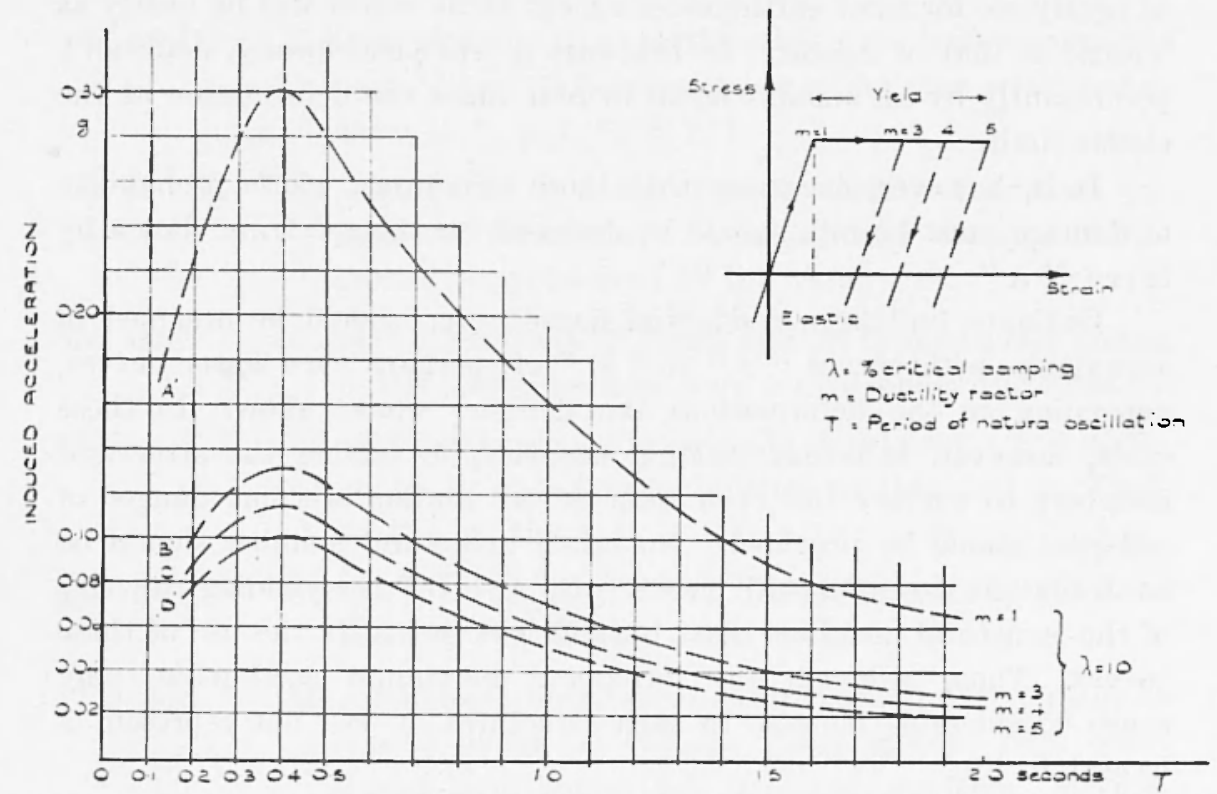

Fig. 3

Except for extremely important engineering structures, such as certain types of dams, nuclear power stations, oil refineries, etc., this approach will be extremely uneconomical and in some instances unrealistic. A reasonable approach would be to use elastic design methods for ordinary structure so that they can withstand relatively frequent earthquakes of a lower intensity than that represented by curve " $A$ ". In the event of a severe earthquake, such as curve " $A$ " implies, some plastic yield may be permitted. For most structural materials, yielding, or plastic deformations of the order of three times the deformation at the elastic limit (*) will involve no serious distortions or indue amount

(*) I.e. total deformation corresponding to a ductility factor $n=4$. 
of damage. The yielding in most structures of stable configuration is of a local nature and does not affect their general appearance. Consequently, it seems reasonable to use in the design ductility factors $\left({ }^{5},{ }^{28}\right)$ between 3 and 5 . In Figure 3 the acceleration spectra for a damping factor of $10 \%$ and for ductility 3,4 and 5 are shown. The use of curve " $\mathrm{C}$ " for instance, implies that, if the structure is designed to withstand accelerations described by this curve, the structure will behave elastically, or nearly so, for most earthquakes except those which will be nearly as intense as that of Agadir. In this case it will yield locally, deforming permenantly by an amount equal to four times the deformation at the elastic limit.

It is, however, necessary that those structures, whose probability of damage must be nill, should be designed for the spectrum shown by curve "A".

Ordinary buildings, residential houses, etc., should be designed in accordance with curves " $\mathrm{B}$ " to " $\mathrm{D}$ " or, perhaps even lower curves, depending on the deformations the designer would allow. In these cases, however, sufficient yielding capacity, to anable the structural members to survive the even most severe motion without danger of collapse, should be provided. No brittle structural member should be used, since, in designing with curves " $\mathrm{B}$ " to " $\mathrm{D}$ " the yielding capacity of the structural members must be sufficient to justify the use of these curves. Thus, although the infrequent maximum earthquake may cause considerable damage to such structures, it will not represent a hazard to life.

Examination of the damage caused by the Agadir earthquake shows clearly that the structures had little yield capacity. The brittle materials and unstable forms of construction used were unable to withstand deformations beyond the elastic limit with the result that, even a relatively small deformation, caused complete collapse of many of the structures $(11,17)$.

\section{6. - SEISMIC SEA-WAVES.}

Little information regarding the occurrence of seismic sea waves on the Tunisian coast is available, except that reported in Rothè's catalogue $\left(^{*}\right)$ for the 1905 earthquake in the Bizerta area. blishod).

(*) "Catalogue des seimes Tunisiens", Strasbourg, June 1962 (unpu. 
Note: Part of the work in this paper has been taken from a report prepared by the author for the Cementation Co. Ltd, March 1962, London S.E.I.

List of MaIor EaRTiLUAKES IN TUNisia.

408 or $412 \quad \Lambda$ series of destructive earthquakes with fault movements near Utica. Aftershocks lasted for one week (references in ${ }^{21}$, p. $7{ }^{27}$, p. 871).

854 or 855 An earthquake in north Tunisia destroyed thirteen villages at Kairowan. Slumping and settling of the ground was observed in the valleys. $\left.{ }^{1}\right)$.

856 Dec. A great earthquake at Tunis and its dependencies during which 45.000 persons were buried under the ruins ( ${ }^{1}$ ).

1724

An earthquake shock principally in Algiers. The earthquake extended from Miliana to Bon and in Tunisia. $\left({ }^{21}\right)$, p. 122 .

1750 oct. 5 A strong earthquake shook north Africa fron Sfax to Bon. $\left({ }^{14}\right) \cdot\left({ }^{21}\right)$, p. 148 .

1758 Jan. $\quad$ An earthquake near Constantine caused great damage to several places in Tunisia. Tunis suffered from other shocks and houses fell in great numbers. Several thousand people perished in the ruins. From references in $\left.{ }^{(21}\right)$, p. 133.

1863 Sep. 18 A serie of earthquakes in Tunisia. $\left({ }^{27}\right)$, p. 871.

1864 During this year Tunis was shaken four times by violent earthquakes. $\left({ }^{23}\right)$.

1881 Jun. Numerous strong shocks at Gabes and Maret. The shocks were felt within a radius of $50 \mathrm{kms}$. No damage. $\left({ }^{23}\right)$, p. 612 , $\left({ }^{27}\right)$, p. 871.

1887 Jan. 6 An earthquake in Tunis which caused light damage to village near Ejenel? (Press reports London).

1905 Jul. 29 Light shocks at Sfax. $\left({ }^{27}\right)$, p. 871.

1905 Oct. On 15 th and 22 nd strong shocks were felt at Madhia. $\mathrm{I}_{\mathrm{n}}=\mathrm{V} .\left({ }^{27}\right)$, p. 871 . 
1920 Feb. 25 An earthquake of mannitude 5.9 shook the area around Sbeitla. $\left.{ }^{13}\right)$, p. 214 (Press reports, London). More shocks followed in February and April.

1940 Light shocks were felt in Tunis throughout the year. $\left({ }^{24}\right)$, p. 59,1942 .

1941 Aug. 7 A strong earthquake caused some damage at Bou-Saadiah in the Caidat of Zaghouan. $\left.{ }^{(24}\right)$, p. 5, p. 50, 1954.

1948 May 19 An earthquake of intensity VI shook Tunis. The epicentre was on the Djabel Naheli. $\left({ }^{24}\right)$, p. 24, 1951.

1949 May 7 A local shock caused some damage at Sousse. $\left({ }^{24}\right)$, p. 25, 1953.

1950 Nov 15 An earthquake shock was felt in Tunis. $\left({ }^{24}\right)$, p. $25,1953$.

1953 Jan. 11 Numerous shocks which lasted till the 14th January caused some damage in the region of Cape Bon. (24), p. 16,1955 .

1953 Oct. 17 An earthquake shock at Kairouan. No damage. ( $\left.{ }^{24}\right)$, p. 16,1955 .

1957 Feb. 20 A severe earthquake of magniturle 5.6 occurred on the extension of the Maritime Atlas. The epicentre was a few miles south of Souk-el-Khemis. A number of abode houses were destroyed at Riabna La Merja, Berdaj, Rhardimaou. 13 persons were killed and 96 were injured. The main shock was followed by nine strong aftershocks. $\left({ }^{24}\right)$, p. 9,$1959 ;\left({ }^{6}\right)$, p. $287,1957$.

1958 Aug. 12 A Roman amphitheatre was clamaged and some abode houses collapsed when intermitted shocks shook the area of El-Djem. No casualties were reporterl. $\left({ }^{6}\right)$, p. 115, 1959 (Press reports, London).

\section{$S U M M A R Y$}

Tunis lies well within a seismic zone, the zone of the Atlas, where earthquakes are likely to occur. The city and its neighbouring region has been shaken a number of times recently by moderate earthquakes, and although during the last few hundred years no major earthqualies are linown. to have occurred at Tunis, there is very little doubt that the area neighbouring the city is seismically unstable. 
The tectomies and the seismicity of North Tunisia are not wetl linourn. Important conomical decelopments in that country malie the need for an immediate assessment of the earthqualie danger in Sorth Tunisia and in particular in the Tunis area.

In what follors, a brief study of the tectomies and seismicity of Sorth Tumisin is given, and a standard acceleration spectrum for the design of enginesing structures in the Tumis area is proposed.

\section{RISSUNTO}

Tunisi si estende all:interno di una zona sismica, la zona dell Atlante. La cittic a suoi dintorni sono stati colpriti, recentemente, da moderati terremoti

sebbene, durante gli ultimi secoli, non si siano aruti in detta zona. teremoti cospricui, resta sempre il dubbio civea l'esistenza. intorno alla cittì, di una zona sismicamente instabile. La sismicitì e la tottonien della Tunisia settentrionale, non somo ben conseciute.

Iieconomia di questo Puese, in fase di notecole sciluppo, richiede una immediata ralutazione di crentuali damni da teremoto in tatta la zoma. Sella nota viene brevemente studiata la tettonica e la sismiciti della Tunisia settentrionale. e si propone uno spettro standard dellacederazione per una futura edilizia in Tumisia.

\section{REFERENCES}

(1) Ambrasers X., "On tlie seismicity of soluth-west Asia ". Revue pour lEtudes des Calamites, 37, 7 , Genève, (1961).

$\Leftrightarrow$ Axpersox A., "Jateral forces of earthquake and wind" Tras. Amer. Soc. Civil. Eny., 117, 732, (1952).

(3) Batrone DE M., Les tremblements de terre. Geographie seismologique. Publ. Armand Colin. Paris, (1906).

(4) Barkov A., Fijicheskaya geografiya chastej sceta-.lprika. Publ. Uspedigiz., 234, IIoskow. (1953).

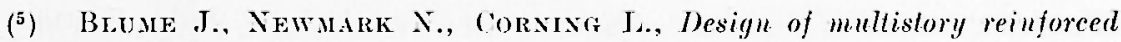
conerete buildings for earthquale motions. Publ. Portland Cement Ass., 318, Chicago, (1961).

$\left.{ }^{6}\right)$ Bulletin of the Seismological Society of America, Seismological Notes, Berlieley California, 1911 onwards.

(i) Rulletin of the Lnion Geodesique ef Geophysique Internat., Bureau Contral Seismologique, Strasbourg, 1943 on.

(") Castaxy G.. "Etude geologique de l'Atlas Tunisien Oriental". Anuales des Mines, 8, Besancon. (1951). 
(9) Castons (i., Carte geologique de la Tunisie. Serbice des Mines Publ., Tunis, (1953).

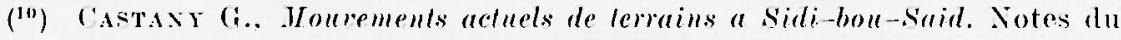
service (ieologique, 10, Tunis, (1954).

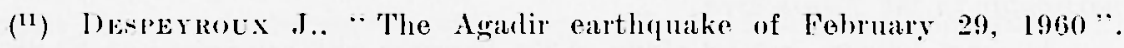
Proce. ?nd Itorld Cont. Earlhquale Eingineering. 1, 521, 589, Tokyo, (1960).

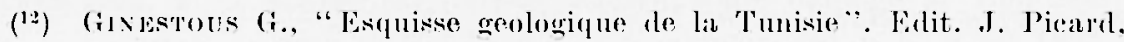
Tunis, (1911).

(13) Getexnert; B., Richter (., Seismicily of the earth. Princeton Lniv. Press, (1954).

(1.) IloF K. vax, Chonil der Erdbeben und Vullan-dusbruche. Gesehl. Chorlieferung nachew. naturl. Verander Erdoberflache, is vols, (iotha. $(1 s+1)$.

('i5) IIol.t.Is E., Bibliography of engineering seismology. Publ. Earthquake Engineering Research lnstitute, 14t, San Francisco, (1958).

$\left.{ }^{16}\right)$ International Seismological summary. Rer Observatory, Richmomat, 1913 onwards.

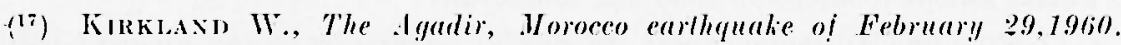
Publ. Committee of Steel Producers, 66, New York, (1962).

(19) KRexkes, E., Die Seismisiläl dfrikas. Zentralblatt fur Mineralogie Geologie und laaliontologie, 6, stuttgart, (1923).

(19) Krexket, E., Geologie Afrikas. 1 of the (Geologie der Erte'. Publ. (ichruder Borntager, Berlin (1925).

(20) Dapparext A., Legons de geographie physique, Eal. Masson. Paris. 1896.

(21) Mataet R., Facts of earlhquale phenomena. Report of the British Association for the divancement of science (1852-8).

(22) MuTo K., Eitarthquate resistant (design) regulations of the world. Publ. Gakujutsu Dunken Fukyu-Kai, Meguroku, Tokyo 1960.

${ }^{(23)} 0$ ' RELLx .J., Alphabetical catalogue of the earthqualies recorded etc. in Europe and adjacent countries ete. Trans. Royal Irish Acadeny. 28. 687, Dublin, (1885).

(2-4) Revue pour lEtude des Calamiles, (ienceve, 1939, onwards.

(25) Rotrue J. P., " chronique seismologique". Revue El. Calam. 32. (1951).

(26) Savornis J., La geologie Algérienne el Nord-dfrianin. Publ. Bastide. Jourdan, Algiers, (1931).

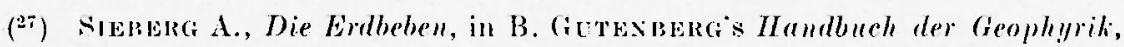
4. Publ. (iebruder Borntrager. Berlin, (1932).

${ }^{(28)}$ Vendersos A., Newmark N., Elfiects of inelastic behaviour of simple systems to earlhqualie motions. Proc. 2nd World conf. Earthquake Engin., 2, 895, T'okyo, (1960). 